Henning Bergenholtz \& Finn Frandsen

\title{
At anmelde i \\ Hermes - tidsskrift for sprogforskning
}

\section{Historisk indledning}

Hermes - tidsskrift for sprogforskning udgives som bekendt af Det erhvervssproglige Fakultet ved Handelshøjskolen i Århus og har eksisteret siden 1988. I de atten numre, der hidtil er blevet udsendt, har der været anmeldelser i hvert eneste nummer. De numre, hvor der har været færrest anmeldelser, er Hermes nr. 1 og 4, hvor kun to værker blev anmeldt (over henholdsvis 11 og 19 sider). Det nummer, hvor der har været flest, er Hermes nr. 13, hvor hele fjorten værker blev anmeldt (over i alt 69 sider). Med til billedet hører, at Hermes nr. 1 og 4 var på henholdsvis 255 sider og 158 sider, mens Hermes nr. 13 var på ikke mindre end 376 sider.

Grunden til, at der var færre anmeldelser i de første numre, var den enkle, at forlagene endnu ikke var begyndt at sende anmeldereksemplarer af deres udgivelser, og at der derudover også går lidt tid fra en tidsskriftsredaktion modtager en bog til anmeldelsen af den offentliggøres.

Tabel 1 viser anmeldersektionens udvikling, hvad angår antallet af anmeldelser og sider i anmeldersektionen.

De vigtigste omslag i tidsskriftets historie hvad angår anmeldelser er Hermes nr. 6, hvor redaktionen besluttede at anlægge en mere international redaktionslinje med flere artikler og anmeldelser på fremmedsprog (engelsk, tysk, fransk, svensk og norsk) - og i det hele taget bringe flere anmeldelser - samt Hermes nr. 12, hvorefter anmeldelserne blev bragt i et særligt layout, således at der kunne offentliggøres flere anmeldelser i det samme nummer. Når der således ved Hermes nr. 13 står angivet 69 sider - det samme antal sider som ved Hermes nr. 9 - er der altså i virkeligheden tale om en langt større tekstmasse.

Generelt kan man sige om de første numre af Hermes, at alle var lige, og ingen var mere lige end andre, dvs. anmeldelserne kunne have samme omfang som artiklerne, nemlig højst 25 trykte sider. Anmeldelserne blev alle sat i samme skrifttype og punktstørrelse som artiklerne, 


\begin{tabular}{|c|c|c|}
\hline Hermes nr. & Antal anmeldelse & Antal sider \\
\hline Nr. 1 & 2 & 11 \\
\hline Nr. 2 & 4 & 28 \\
\hline Nr. 3 & 3 & 15 \\
\hline Nr. 4 & 2 & 19 \\
\hline Nr. 5 & 3 & 20 \\
\hline Nr. 6 & 7 & 63 \\
\hline Nr. 7 & 9 & 65 \\
\hline Nr. 8 & 7 & 60 \\
\hline Nr. 9 & 5 & 24 \\
\hline Nr. 10 & 8 & 61 \\
\hline Nr. 11 & 5 & 35 \\
\hline Nr. 12 & 11 & 43 \\
\hline Nr. 13 & 14 & 69 \\
\hline Nr. 14 & 13 & 65 \\
\hline Nr. 15 & 6 & 45 \\
\hline Nr. 16 & 11 & 46 \\
\hline Nr. 17 & 8 & 34 \\
\hline Nr. 18 & 9 & 48 \\
\hline SUM & 127 & 751 \\
\hline
\end{tabular}

Tabel 1. Udviklingen i antallet af anmeldelser $i$ Hermes

Bemærkning: En anmeldelse er her defineret som en selvstændig tekst, hvori mindst ét værk omtales eller anmeldes. Antallet af anmeldte værker svarer med andre ord ikke nødvendigvis til antallet af anmeldelser.

de begyndte alle på en højre side, og alle anmeldere modtog særtryk. Der blev heller ikke skelnet imellem, om der var tale om en kort omtale, en egentlig anmeldelse eller en review article.

Denne anmeldelsespolitik var ikke blevet fastlagt eksplicit og nedskrevet af redaktionen. Det blev bare gjort sådan. Vi kan derfor ikke redegøre for redaktionens grunde til denne politik, men kun henvise til vores egen hukommelse og til de anmeldelser, som står i de første numre af Hermes.

Den daværende anmeldelsespolitik havde mange positive sider, men det er selvfølgelig teknisk set upraktisk og tilmed ret dyrt for et nyt fagtidsskrift med et beskedent oplag, når en 1 1/2 sides anmeldelse skal have eget særtryk. Det samme gælder, når en 2 1/2 sides anmeldelse skal begynde på en ny højre side. Men principielt kunne denne trykketekniske holdning føre til, at såvel anmeldere som læsere ville opfatte anmeldelser som et seriøst bidrag til den videnskabelige diskurs, et 
bidrag, der kunne føre til yderligere diskussioner såvel i form af svar på anmeldelser som ved citater og reaktioner i videnskabelige artikler.

Tabel 2 viser, hvordan anmeldelserne i Hermes er fordelt på forskellige lingvistiske eller nært beslægtede forskningsområder. Vi har valgt at udelade parametre som fagsprog/almensprog og videnskabeligt vark/ larebog, selv om de uden tvivl også ville være med til at differentiere Hermes i forhold til andre lingvistiske fagtidsskrifter.

Forskningsområde Antal anmeldte publikationer

\begin{tabular}{|l|c|}
\hline Leksikografi og terminologi & 45 \\
\hline Grammatik & 33 \\
\hline Oversættelsesteori & 11 \\
\hline Tekstlingvistik og diskursanalyse & 7 \\
\hline Retorik og stilistik & 6 \\
\hline Pragmatik & 5 \\
\hline Kommunikationsteori & 5 \\
\hline Sprogpolitik & 4 \\
\hline Tolkeforskning & 2 \\
\hline Sociolingvistik & 2 \\
\hline Semantik & 2 \\
\hline (Fremmed)sprogstilegnelse & 1 \\
\hline Sproghistorie & 1 \\
\hline Varia & 4 \\
\hline
\end{tabular}

\section{Tabel 2. Anmeldelser i Hermes fordelt på forskningsområder}

Bemærkning: Betegnelsen grammatik dækker over såvel fonetik, morfologi, syntaks, tegnsætning og ortografi. Betegnelsen kommunikationsteori dækker over områder som f.eks. fagsproglig kommunikation og interkulturel kommunikation. Betegnelsen varia dækker over værker som f.eks. kongresakter eller festskrifter, hvor flere forskningsområder er behandlet.

Som det fremgår, har det især været leksikografiske/terminologiske og grammatiske værker, som er blevet anmeldt i Hermes, men også en stor del værker inden for oversættelsesteori er blevet omtalt. Det skal dog understreges, at Hermes anmelder lingvistisk faglitteratur i bredeste forstand, og at det billede, tabel 2 tegner, lige så meget er udtryk for, hvad forlagene har sendt os, og hvilken faglig interesse anmelderne har haft, som for en tilstræbt anmeldelsespolitik, hvad angår indholdet. 


\section{Anmeldelsens funktion}

Hvad skal en god anmeldelse indeholde? Derom hersker der delte meninger, men følgende elementer vil normalt indgå:

(1) en beskrivelse af det anmeldte værks indhold;

(2) en positiv eller negativ vurdering af værket samt en begrundelse for denne vurdering; og

(3) en anbefaling (eller det modsatte) af værket til læserne.

Om alle tre elementer bør være obligatoriske i alle typer anmeldelser kan diskuteres. Hvis der blot er tale om en kort informativ omtale af et værk, kan vurderingen normalt udelades. Er der derimod tale om en egentlig anmeldelse eller en review article over flere sider, kommer man ikke uden om vurderingen samt evt. helt andre elementer som f.eks. en placering af værket i forhold til en forsknings- eller institutionshistorie. I praksis vil det dog være svært at foretage en skarp skelnen mellem de nævnte undergenrer, og man må derfor nok nøjes med at anse beskrivelsen som det eneste obligatoriske element.

De fleste almensproglige ordbøger anser dog vurderingen som en væsentlig del af den leksikografiske definition af en anmeldelse, f.eks. Klappenbach/Steinitz:

Rezension [...]

1. kritische Besprechung, Beurteilung einer wissenschaftlichen oder künstlerischen Leistung in einer Zeitschrift oder Zeitung, im Rundfunk oder Fernsehen [...]

og Nudansk Ordbog:

Anmeldelse [...]

2. vurderende omtale af en bog, et teaterstykke, en koncert el. en udstilling i et dagblad el. tidsskrift

$=$ kritik, recension, omtale

En anmeldelse behøver ikke at kun at koncentrere sig om en enkelt udgivelse. Der kan udmærket anmeldes flere publikationer i samme anmeldelse. Derimod er det ikke hensigtsmæssigt at tale om en anmeldelse, når der foretages en kritisk behandling af en bog eller en artikel som del af f.eks. en forskningsoversigt i en afhandling. På den anden side er denne form for kritik meget vigtig i den videnskabelige diskurs, og det er også vigtigt at se sammenhængen mellem anmeldelser og kritiske gennemgange som del af en større fremstilling. Her er der flydende grænser. 


\section{Typer af anmeldelser og typer af modtagere}

Man kan skelne mellem følgende typer af anmeldelser og typer af modtagere:

1. Udførlige anmeldelser (review articles) for fagfolk

2. Korte anmeldelser for fagfolk

3. Udførlige anmeldelser (review articles) for fagfolk og lægfolk

4. Korte anmeldelser for fagfolk og lægfolk

5. Omtaler for fagfolk og lægfolk

En stor del af den diskussion om anmeldelser, der har fundet sted på vores redaktionsmøder, har hængt sammen med redaktionsmedlemmernes forskellige opfattelser af, hvilken type anmeldelse et omnibustidsskrift som Hermes bør sigte imod. Hos flertallet i redaktionen har der været en tendens til at sigte mod den tredje af de ovennævnte typer, hvorimod et mindretal har været fortaler for den første type.

\section{Hvad kan anmeldelser bruges til?}

Vi må her diskutere noget, der minder om leksikografiens brugertyper og brugssituationer. Vi kan - svarende til Bergenholtz/Mogensen (1993) - skelne mellen følgende situationer og typer:

- Brugere: information om eksistensen og nytteværdien af et værk

- Undervisere på forskellige niveauer: information om eksistensen og nytteværdien af et værk ud fra overvejelsen om at anbefale det eller lade det anskaffe til de studerende

- Den anmeldte: bedømmelser fra videnskabelig og ikke-videnskabelig side

- Forlaget: information om eksistensen af et værk, men også en vurdering af dets værdi og derved til en vis grad også dets chance for at blive solgt

- Andre fagfolk: information om et nyt værk og om nye tendenser, herunder også information om nytten af selv købe eller læse det pågældende værk

Derimod anser vi det ikke som en anmeldelses eneste eller vigtigste funktion at være en opfordring til at købe eller ikke at købe et værk, som hævdet af f.eks. Balsgart (1993, 65-94). En undtagelse herfra kan måske være bidrag i ibc med lektørudtalelser til bibliotekarer. 


\section{Hvilke publikationer kan anmeldes?}

Når et fagtidsskrift er blevet etableret, vil det hurtigt komme i den fordelagtige situation, at der indsendes så mange publikationer, at de ikke alle vil kunne anmeldes. Man må da foretage en eller anden form for udvælgelse, herunder også et valg af undergenrer (omtale, egentlig anmeldelse eller review article). Man kan naturligvis også vælge at undlade at anmelde en publikation. I denne forbindelse rejser der sig en række spørgsmål: Skal bogen være ny? Skal den have en bestemt kvalitet? Kan man anmelde en bog, der allerede er udsolgt? Kan man anmelde en bog, som et forlag har trukket eller vil trække tilbage på grund af bestemte mangler eller fejl? Kan eller bør man lade et rent genoptryk anmelde? Og hvordan forholder det sig med en revideret udgave?

Vi kan naturligvis ikke besvare alle disse spørgsmål her, men principielt kan man vel let blive enige om, at en helt ny bog har større chancer for at blive anmeldt end et genoptryk eller en revideret udgave. I praksis vil der dog være en lang række situationer, hvor der ikke umiddelbart kan opnås enighed. Laursen/Tarp (1992) er et eksempel på en sådan uenighed i Hermes' redaktion. Det drejer sig om en anmeldelse af en (dengang) ny dansk-spansk handelsordbog. Ordbogen havde mindst to interessante aspekter: 1) det var den første dansk-spanske handelsordbog og 2) ordbogen var billig (godt $100 \mathrm{kr}$ ). Laursen/Tarp påviste i deres anmeldelse, at bogen sprogligt og fagligt var fyldt med fejl, unøjagtigheder og mangler, sådan som Rossenbeck (1981) har gjort det med en svensk-tysk økonomisk ordbog. Laursen/Tarp indsendte anmeldelsen til udgivelse i Hermes og sendte samtidig en kopi til forlaget. Forlæggeren takkede for tilsendelsen og meddelte redaktionen, at ordbogen ville blive trukket tilbage fra boghandlerne. I løbet af kort tid ville i stedet man udsende en ny og forbedret udgave. Spørgsmålet for redaktionen $\mathrm{i}$ et sådant tilfælde er, om man kan og skal anmelde en sådan ordbog, som forlaget vil trække tilbage. Et flertal i Hermes' redaktion mente nej og afviste anmeldelsen, som så blev trykt et andet sted.

Set i bagspejlet må vi sige, at redaktionens afgørelse ikke var heldig. Ordbogen var jo allerede blevet solgt, også til biblioteker, som forsat stillede ordbogen til rådighed. I $\emptyset$ vrigt kunne ordbogen flere måneder senere stadig købes i en af de største boghandler i Århus. Og da ordbogen endelig kom i et nyt oplag, var ændringerne ganske få. Men det er en anden historie. Generelt kan man af dette forløb lære, at nye bøger bør kunne anmeldes, også hvis bogen er trukket tilbage eller udsolgt. 
Derudover må moralen være, at ingen anmeldelse bør sendes til den anmeldte eller den anmeldtes forlag, før anmeldelsen er offentliggjort.

Den pågældende anmeldelse blev i $\emptyset$ vrigt afvist med en dobbelt begrundelse: det var ikke bare en anmeldelse af en tilbagetrukket ordbog (som derfor ikke skulle anmeldes), men anmeldelsen var også for lang. I modsætning til praksis i de første numre besluttede redaktionen nemlig i 1991, at anmeldelser kun måtte omfatte 4-6 trykte sider, og den omtalte anmeldelse var på 12 sider.

Man kan selvfølgelig diskutere, om en anmeldelse ikke kan blive så lang og omfattende, at der ikke længere er tale om en anmeldelse. Der er flere eksempler på dette i leksikografien, f.eks. Wiegand/Kucera's godt 300 sider lange anmeldelse af Brockhaus/Wahrig (Wiegand/ Kucera 1981, 1982) og Bergenholtz/Mugdan's 149 sider lange anmeldelse af Duden-Universalwörterbuch (Bergenholtz/Mugdan 1986), en anmeldelse, som i $\emptyset$ vrigt blev fulgt op i Hermes efter udsendelse af samme ordbog med dansk smudsomslag (Bergenholtz/Mugdan 1991). Denne anmeldelse med sine 22 trykte sider ville i $\emptyset$ vrigt kun være blevet optaget i et senere nummer, dvs. i Hermes nr. 7 og derefter, hvis den efter redaktionens opfattelse ville kunne opfattes som en review article med en mere generel behandling af fagets status.

\section{Hvem kan anmelde?}

Ethvert tidsskrift har et netværk, hvorfra man ud fra personligt og fagligt kendskab søger at udvælge den mest kvalificerede anmelder til en bestemt publikation. Valg af anmelder kan være forbundet med flere overvejelser. Kan og bør man finde en anmelder, som ikke er ansat på samme institution som bogens forfatter? Hvordan skal man forholde sig, hvis en potentiel anmelder er kendt for at være stærkt kritisk over for en bestemt forfatter? Kan man anmelde en bog, som salgsmæssigt og/eller videnskabeligt står i et konkurrenceforhold til egne værker? Principielt bør man selvfølgelig foretrække en anmelder, hvor svaret på alle de ovennævnte spørgsmål er, at der ingen kontakt har været mellem anmelder og den anmeldte. I praksis er det ikke altid let selv inden for et stort sprogområde, og inden for et lille sprogområde vil det ofte være umuligt. Eller sagt på en anden måde: Mange bøger ville slet ikke kunne anmeldes, hvis enhver relation mellem anmelder og anmeldt er diskvalificerende. En vej ud af dette dilemme kan være, at anmelderen i begyndelsen af sit bidrag gør opmærksom på forhold, hvor en helt 
objektiv anmeldelse kunne betvivles. Dette er f.eks. blevet gjort flere gange i anmeldelser i tidsskriftet LexicoNordica, sandsynligvis under påvirkning af redaktørernes forord, hvor de opfordrede til en sådan praksis (Bergenholtz/Malmgren 1995, 1-2).

Det nævnte dilemma eksisterer kun, hvis anmelderen vælges blandt de rene fageksperter. Man kunne i stedet vælge at lade en anmeldelse skrive af en "helt normal" læser, f.eks. af en ordbogsbruger. Dette er faktisk tilfældet i de fleste aviser, hvor journalister uden særligt kendskab til leksikografi normalt skriver ordbogsanmeldelser. Der kan være mange fordele ved dette, idet en sådan anmelder ikke bliver forstyrret eller forblændet af en bestemt baggrundsteori, men alene anmelder ud fra normal brug. I andre tilfælde er en sådan inddragen af lægfolk som anmeldere undtagelsen. Kun ved mindre provinsaviser er det almindeligt, at anmeldelsen af en koncert bliver skrevet af en medarbejder, der ikke har stort kendskab til både musikteori og den nuværende musikscene. På samme måde er det heller ikke almindeligt at bede en tilfældig journalist om at anmelde et teaterstykke eller et nyudkomment skønlitterært værk.

I et lingvistisk fagtidskrift vil man have det problem, at det nogle gange er svært at finde en anmelder, som dækker hele området. Og hvis en sådan ekspert findes, vil vedkommende måske ikke egne sig som anmelder af en lærebog i emnet, fordi vedkommende har "glemt", hvad en begynder ikke ved eller kan lære? Men dilemmaet er reelt. Anmelderen burde både være fagmand og bruger på én gang. En praktisk løsning kunne være, at man som ovenfor nævnt bragte flere dobbeltanmeldelser. Vi kan nævne et sådant tilfælde i LexicoNordica, hvor en leksikograf anmeldte en dansk-engelsk ordbog (Pedersen 1996), som blev afsluttet med en bedømmelse af leksikografens datter, der gik i gymnasiet og kunne berette om erfaringer med brug af denne ordbog. Et andet eksempel er en anmeldelse af en dansk-engelsk medicinsk ordbog, som blev anmeldt i fællesskab af en leksikograf og en mediciner (Axelsen/ Broen-Christensen 1995).

\section{Reaktion på anmeldelser}

Når og hvis en anmeldt forfatter føler, at visse dele af en anmeldelse er misvisende, kan han eller hun naturligvis prøve at få sin reaktion trykt i samme tidsskrift. Vi har flere eksempler på dette i Hermes, f.eks. 
Blaaberg (1991) som reaktion på Møller (1990), Kaufmann (1993a) og (1993b) som reaktion på henholdsvis Balsgart (1993) og Grinsted/Toft (1993). Men det er ikke et princip i Hermes, sådan som det f.eks. er fastlagt af redaktionen for LexicoNordica, men måske kunne det gøres til et princip, at alle anmeldte forfattere fik tilsendt den trykte anmeldelse med en henvisning til muligheden for at reagere. I så fald bør man dog

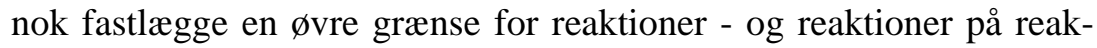
tioner, f.eks. et svar fra den anmeldte og hertil et gensvar fra anmelderen.

\section{Oversigt over danske ordbogsanmeldelser}

Tabel 3 viser resultaterne af en undersøgelse af i alt 252 danske ordbogsanmeldelser i lingvistiske fagtidsskrifter. Summen af angivelser i den enkelte spalte kan overstige summen af gennemsete anmeldelser, da flere anmeldelser beskriver flere ordbøger (jf. bemærkning til tabel 1), og nogle anmeldelser i flere forskellige sammenhænge går ind på en bestemt anmeldelseskategori.

Der er to påfaldende tendenser. Den ene fremgår direkte, idet rubrikken lemmaselektion (udvalg af opslagsord) udgør en uforholdsmæssig stor del af samtlige udsagn i anmeldelserne. Den anden tendens fremgår ikke direkte, men hvis man sammenholder de omkring $90 \%$ negative udsagn om konkrete ordbogsdele med "positiv samlet bedømmelse", kan man se en ejendommelig diskrepans mellem indholdet af anmeldelsen og dennes egen konklussion, idet der nu er blevet til $90 \%$ positive helhedsindtryk. En lignende unders $\emptyset$ gelse af alle anmeldelser i Hermes er endnu ikke blevet foretaget, men vi har dog det indtryk, at denne tendens er særlig påfaldende ved ordbogsanmeldelser, men heller ikke ualmindelig ved anmeldelser af andre former for publikationer. En større overensstemmelse mellem anmeldelsens helhedsbedømmelse og summen af de enkelte udsagn ville være ønskværdig. 


\begin{tabular}{|c|c|c|c|c|c|}
\hline $\begin{array}{l}\text { ANMELDELSESTYPE } \\
\text { ANMELDELSESKATEGORI }\end{array}$ & $\begin{array}{c}\text { Udførlige } \\
\text { anmeldelser } \\
\text { (review } \\
\text { articles) for } \\
\text { leksiko-grafer } \\
0\end{array}$ & $\begin{array}{l}\text { Korte } \\
\text { anmeldelser } \\
\text { for leksiko- } \\
\text { grafer } \\
\\
3\end{array}$ & $\begin{array}{l}\text { Udførlige } \\
\text { anmeldelser } \\
\text { (review } \\
\text { articles) for } \\
\text { brugere (og } \\
\text { leks.) } \\
43\end{array}$ & $\begin{array}{l}\text { Korte } \\
\text { anmeldelser } \\
\text { for brugere } \\
\text { (og leks.) } \\
\\
106\end{array}$ & $\begin{array}{c}\text { Omtale for } \\
\text { brugere } \\
\text { (og leks.) } \\
100\end{array}$ \\
\hline $\begin{array}{l}\text { ordbogsbrugere } \\
\text { ordbogsbrugeresituationer } \\
\text { råd til brugerne } \\
\text { pris } \\
\text { layout } \\
\text { om ordbogsforfatteren } \\
\text { sammenligning med andre ordbøger } \\
\text { ordbogens forhistorie } \\
\text { henvisning til andre anmeldelser } \\
\text { empirisk basis } \\
\text { omtekst } \\
\text { lemmaselektion } \\
\text { lemmaanordning } \\
\text { præskriptiv/deskriptiv } \\
\text { ækvalenter } \\
\text { grammatik } \\
\text { retskrivning } \\
\text { udtale } \\
\text { semantik } \\
\text { diasystematiske angivelser } \\
\text { etymologi } \\
\text { eksempler } \\
\text { kollokationer } \\
\text { illustrationer } \\
\text { synonymi/antonymi } \\
\text { ordbogens underholdningsværdi } \\
\text { positiv samlet bedømmelse } \\
\text { negativ samlet bedømmelse }\end{array}$ & $\begin{array}{l}0 \\
0 \\
0 \\
0 \\
0 \\
0 \\
0 \\
0 \\
0 \\
0 \\
0 \\
0 \\
0 \\
0 \\
0 \\
0 \\
0 \\
0 \\
0 \\
0 \\
0 \\
0 \\
0 \\
0 \\
0 \\
0 \\
0 \\
0\end{array}$ & $\begin{array}{r}2 \\
1 \\
1 \\
0 \\
2 \\
0 \\
0 \\
0 \\
1 \\
0 \\
3 \\
12 \\
0 \\
0 \\
0 \\
1 \\
0 \\
0 \\
0 \\
3 \\
0 \\
2 \\
2 \\
1 \\
0 \\
0 \\
2 \\
0\end{array}$ & $\begin{array}{r}30 \\
36 \\
3 \\
8 \\
36 \\
9 \\
39 \\
18 \\
13 \\
18 \\
29 \\
184 \\
17 \\
3 \\
114 \\
70 \\
6 \\
20 \\
35 \\
51 \\
2 \\
21 \\
41 \\
5 \\
24 \\
4 \\
40 \\
15\end{array}$ & $\begin{array}{r}47 \\
37 \\
4 \\
30 \\
39 \\
33 \\
42 \\
30 \\
4 \\
12 \\
35 \\
175 \\
10 \\
7 \\
65 \\
27 \\
18 \\
37 \\
32 \\
22 \\
6 \\
5 \\
24 \\
15 \\
6 \\
12 \\
63 \\
2\end{array}$ & $\begin{array}{r}21 \\
16 \\
4 \\
56 \\
34 \\
6 \\
6 \\
22 \\
0 \\
2 \\
15 \\
84 \\
6 \\
0 \\
19 \\
11 \\
5 \\
12 \\
0 \\
2 \\
1 \\
1 \\
3 \\
10 \\
0 \\
0 \\
39 \\
0\end{array}$ \\
\hline
\end{tabular}

Tabel 3. Oversigt over danske ordbogsanmeldelser 


\section{Anmelderens "metode"}

Kan man skelne mellem en god og en dårlig anmeldelse? Det kan man nok til en vis grad, men man må dog også samtidig skelne mellem forskellige aktører eller synsvinkler: 1) den anmeldte forfatter hhv. dennes forlægger, 2) anmelderen hhv. den publikation, anmeldelsen er trykt i, og endelig 3) læseren. Hvis man sammenstillede en række svar på anmeldelser, både af de anmeldte og af læsere, som påpeger det uretfærdige i en bestemt anmeldelse, vil man uden tvivl komme frem til en lang negativliste, der på mange måder vil være komplementær til den positive liste, der svarer på spørgsmålet: Hvad kendetegner en god anmeldelse? Dette spørgsmål vil vi besvare ved at omskrive Jørgensen (1992) til ti "metodiske bud", der - i det mindste til en vis grad - kan anvendes ved anmeldelsen af lingvistiske fagbøger.

\section{Ti "metodiske bud"}

1. En anmeldelse skal indeholde et koncentreret referat. Men den skal altid være mere end et referat. Den skal give et indtryk af bogen, og den skal formidle interesse.

2. Anmeldelsen skal være kort og klar og give fyldige citater.

3. Den skal indeholde en analyse og en fortolkning og en vurdering. Anmelderen må her argumentere for sine påstande. Også præmisserne for vurderingerne må fremlægges.

4. Anmeldelsen skal være en præsentation og en forbrugerorientering.

5. Anmeldelsen skal sætte noget i gang hos læseren og i det hele taget være inspirerende for meningsdannelsen i samfundet.

6. Den skal være præget af personligt engagement. Og vilje til objektivitet.

7. Anmeldelsen må godt være sjov og samfundskritisk og lidt provokerende.

8. Sproget skal være præcist, men samtidig kreativt. Og så må anmelderen godt have nogle anekdoter $\mathrm{i}$ baghånden.

9. Anmelderen må være håndværksmæssig solidarisk med forfatteren og vel og mærke uden at slække på egne visioner.

10. Kritikken skal være positiv og angive alternativer til det, der kritiseres. 
Den læser, der $\varnothing$ nsker en noget tungere og mere alvorlig tone, kan i stedet nøjes med de syv bud hos Leisi (1993). I selve indholdet er der stor overenstemmelse: En anmeldelse skal være fair, dvs. tage udgangspunkt i værkets egne forudsætninger og beskrive, vurdere, og begrunde vurderingen - samt anbefale/fraråde værket.

\section{Anmeldelsesetik}

Hvis en sådan metodisk fairnes er givet i en anmeldelse, vil man også kunne sige, at den opfylder væsentlige etiske krav. Men der foreligger også en tradition for at formulere konkrete etiske bud. Wiegand (1995) bygger f.eks. på en teologisk tradition, som han omskriver til bud for anmeldelser af ordbøger. Vi omskriver her Wiegands teser til at gælde både leksikografiske og andre lingvistiske værker:

\section{Wiegands ti etiske bud}

1. Der bør stilles etiske krav til en anmeldelse.

2. Et videnskabeligt bidrag er ingen person. Afhold dig derfor fra enhver henvisning til forfatterens person, hans personlige og faglige forudsætninger, hvis disse ikke er alment kendte i forvejen.

3. Når du skriver anmeldelser, så undlad brugen af udråbstegn.

4. Du skal ikke tilintetgøre et værk og dermed værkets forfatter. Også for en anmelder gælder: Du må ikke slå ihjel.

5. Du skal ikke skamrose for på den måde at skaffe dig venner til støtte for din karierre.

6. Vi "maa udlede Hveden blandt Klinten og ikke antage uden dem, som ere gode". En klintesøgende anmelder er at betragte som en skarnbasse i et blomsterbed. Du skal søge hveden, og hvis du ikke finder den, så tænk over, om du er blind på et eller begge øjne.

7. Anse det ikke for egen skarpsindighed at gøre opmærksom på et manglende komma, en enkelt stavefejl eller en anden tilfældig mangel.

8. Det ottende bud gælder også for en anmelder. I stedet for skal du søge efter undskyldninger og i tvivlstilfælde fremhæve det positive.

9. En anmeldelse skal ikke være et forum for en promovering af egne videnskabelige bidrag. Selvros stinker. 
10. En spottende anmelder har det ligesom en professor, der i sin forelæsning gør grin med en kollega. Han vil sikkert have auditoriets bifald, men også pådrage sig gudernes vrede, thi han spotter en forfatter, der ikke kan forsvare sig.

\section{På vej mod en ny anmelderpolitik i Hermes}

Hermes' redaktion har ved et møde den 16.2.1997 vedtaget følgende vedrørende vores anmeldersektion. Ved anmeldelser i Hermes skelnes der imellem:

- $\quad$ korte informerende anmeldelser af typen "omtale", der maksimalt må have et omfang af 2 sider

- $\quad$ længere kommenterende anmeldelser af typen "rigtige anmeldelser" der maksimalt må have et omfang af 6 sider

- meget lange anmeldelser af typen "review articles", f.eks. en anledning til en gennemgang af af en bestemt forsknings "state of the art", der maksimalt må have et omfang af 25 sider.

Denne beslutning vedrører i første omgang kun omfanget. Tilbage står at diskutere, hvordan vi rent indholdsmæssigt vil definere de enkelte undergenrer: omtale, anmeldelse og review article. Er en review article f.eks. blot en mere udførlig anmeldelse, dvs. en anmeldelse, der rummer flere informationer og en større grad af vurdering og begrundelse, end det er tilfældet i en "rigtig" anmeldelse? Eller skal en review article altid indeholde en mere generel beskrivelse af og stillingtagen til udviklingen inden for et bestemt forskningsområde eller en bestemt forskningstradition? Og hvad med den korte omtale? Skal den have en fast opbygning, hvor der udelukkende lægges vægt på det informative? Eller kan den også rumme vurderende elementer - sådan som man kender det fra korte dagsbladsanmeldelser - selv om der ikke er meget plads til at give en begrundelse for vurderingen? Som man ser, der er nok af spørgsmål at tage fat på for Hermes' redaktion.

\section{Referencer}

Axelsen, Jens (1992): En anmeldelse af en anmeldelse. In: Sprint 2, 1-5

Axelsen, Jens /Broen-Christensen, Chr. (1995): [Anm. af Morten Pilegaard \& Helge Baden: Medicinsk ordbog, dansk engelsk, engelsk dansk, i: LexicoNordica 2, 143-146.

Balsgart, Karin (1993): Fag, faglighed og fagordbøger. In: Hermes 10, 65-94. 
Bergenholtz, Henning/Malmgren, Sven-Göran (1995): Förord. In: LexicoNordica 2, 1-3.

Bergenholtz, Henning/Jens Erik Mogensen (1994): Wörterbuchkritik in Dänemark. In: Lexicographica 9, 8-35.

Bergenholtz, Henning/Joachim Mugdan (1986): Der neue "Super-Duden" die authentische Darstellung der deutschen Gegenwartssprache? In: Studien zur neuhochdeutschen Lexikographie VI.1, hrsg. von Herbert Ernst Wiegand. Hildesheim/Zürich/New York: Olms, 1-149.

Bergenholtz, Henning/Joachim Mugdan (1991): [Anmeldelse af Tysk-Tysk Ordbog. København: Munksgaard/Mannheim: Dudenverlag 1989]. In: Hermes 6, 139-160.

Blaaberg, Hanne (1991): Reaktion på Bernt Møllers anmeldelse af Clausens tekniske ordbog dansk-fransk. In: Hermes 7, 115-116.

Grinsted, Annelise/Bertha Toft (1993): [Anmeldelse af Kaufmann/Bergenholtz: Genteknologisk ordbog. København: Gad 1992]. In: Hermes 11, 123129.

Jehle, Günter (1989): Das englische und französische Lernerwörterbuch in der Rezension. Theorie und Praxis der Wörterbuchkritik. Tübingen: Niemeyer.

Jørgensen, John Chr. (1992): Så let er det. Kunsten at skrive gode anmeldelser. In: Politiken 19.9.1992.

Kaufmann, Uwe (1993a): Fagordbøger: Ideal og pragmatik. In: Hermes 11, 117-121.

Kaufmann, Uwe (1993): ... ergo er Morlille en Steen. In: Hermes 11, 131-132.

Laursen, Anna-Lise/Sven Tarp (1992): [Anmeldelse af Hansen: Por muchas razones. Dansk-spansk handelsordbog. Holstebro: Venus 1991]. In: Informationer fra Spansklarerforeningen 47, 50-54.

Leisi, Ernst (1993): Sieben Thesen zum Rezensionswesen. In: Deutsch als Fremdsprache 30, 188-189.

Lenstrup, Rita (1991): Kritiske bemærkninger til artikel af Henning Bergenholtz, Helle Dam og Torben Henriksen. In: Hermes 7, 109-114.

Pedersen Jette/Pedersen, Tine (1996): Jens Axelsen: Dansk-Engelsk Ordbog. In: LexicoNordica 3, 287-294.

Ripfel, Martha (1989): Wörterbuchkritik: eine empirische Analyse von Wörterbuchrezensionen. Tübingen: Niemeyer.

Rossenbeck, Klaus (1981): 'Der *Unfalltüchtige' und 'die *Einundfünfzige' oder: Goddag, yxskaft! In: Germanistisches Bulletin 5. Mitteilungsblattt schwedischer Germanisten. Linköping, 75-103.

Wiegand, Herbert E./Antonín Kucera (1981): Brockhaus-Wahrig. Deutsches Wörterbuch auf dem Prüfstand der praktischen Lexikologie. I. Teil: 1. Band (A-BT); 2. Band (BU-FZ). In: Kopenhagener Beiträge zur Germanistischen Linguistik 18, 94-217. 
Wiegand, Herbert E./Antonín Kucera (1982): Brockhaus-Wahrig. Deutsches Wörterbuch auf dem Prüfstand der praktischen Lexikologie. II. Teil: 1. Band (A-BT); 2. Band (A-BT); 3. Band (G-JZ). In: Wiegand, Herbert E. (Hrsg.): Studien zur neuhochdeutschen Lexikographie II. Hildesheim/ Zürich/New York: Olms, 285-373. 
